\title{
Knowledge about cervical cancer and HPV immunization dropout rate among Brazilian adolescent girls and their guardians
}

\author{
Ana Carolina da Silva Santos ${ }^{1 *}$ (D), Nayara Nascimento Toledo Silva', Cláudia Martins Carneiro², \\ Wendel Coura-Vital ${ }^{1,2}$ and Angélica Alves Lima ${ }^{1}$
}

\begin{abstract}
Background: Infections with Human Papillomavirus (HPV) are the main cause of cervical cancer. Since 2014, the HPV vaccine was introduced in the Brazilian National Vaccination Calendar. The purpose of this study was to assess the knowledge of adolescent girls and their mothers/guardians about HPV and HPV vaccine, identify the factors associated with this knowledge, and evaluate immunization dropout rate.

Methods: This was a cross-sectional study involving adolescent girls and their mothers/guardians. Participants underwent an interview that addressed sociodemographic data, sexual and gynecological history, and knowledge about HPV, HPV vaccine and cervical cancer. The third quartile of the total score was established as a cutoff for assessing knowledge. Adolescents who correctly answered more than four questions and mothers/guardians who obtained more than five correct responses were categorized into high knowledge. Poisson regression analysis was performed to identify variables associated with low knowledge. Vaccination records were used to assess immunization dropout rates. Any adolescent who did not complete the two-dose vaccination schedule was considered dropout.
\end{abstract}

Results: A total of 666 adolescent girls and 623 mothers/guardians were interviewed. Low knowledge was observed in $76.7 \%$ of adolescents and $79.8 \%$ of mothers/guardians. Most were unaware of the causal relationship between HPV and cervical cancer, signs and symptoms of HPV infection, and had limited knowledge about the HPV vaccine. Factors associated with low knowledge of adolescents were aged 12 years [IRR $1.2(95 \% \mathrm{Cl} 1.1-1.3)$ ] or less [IRR 1.3 (95\% Cl (1. 2-1.4)]; household income lower than US\$750 [IRR 1.7 (95\% Cl 1. 1-2.6)] and household income between US\$751 and US\$1500 [IRR 1.6 (95\% Cl 1.0-2.6)]. Among mothers/guardians, low knowledge was related to having completed elementary school or less [IRR $1.5(95 \% \mathrm{Cl} 1.2-2.0)]$; and household income lower than US\$750 [IRR 1.2 (95\% Cl 1.0-1.4)]. Knowledge of adolescents and mothers/guardians was not associated with vaccine uptake. HPV immunization dropout rate was considered high (32.3\%).

(Continued on next page)

\footnotetext{
* Correspondence: anacarolenfermagem@gmail.com

${ }^{1}$ Programa de Pós-graduação em Ciências Farmacêuticas (CiPharma), Escola de Farmácia, Universidade Federal de Ouro Preto, Campus Universitário, Morro do Cruzeiro, Ouro Preto, Minas Gerais 35.400-000, Brazil

Full list of author information is available at the end of the article
}

(c) The Author(s). 2020 Open Access This article is licensed under a Creative Commons Attribution 4.0 International License, which permits use, sharing, adaptation, distribution and reproduction in any medium or format, as long as you give appropriate credit to the original author(s) and the source, provide a link to the Creative Commons licence, and indicate if changes were made. The images or other third party material in this article are included in the article's Creative Commons licence, unless indicated otherwise in a credit line to the material. If material is not included in the article's Creative Commons licence and your intended use is not permitted by statutory regulation or exceeds the permitted use, you will need to obtain permission directly from the copyright holder. To view a copy of this licence, visit http://creativecommons.org/licenses/by/4.0/. The Creative Commons Public Domain Dedication waiver (http://creativecommons.org/publicdomain/zero/1.0/) applies to the data made available in this article, unless otherwise stated in a credit line to the data. 
(Continued from previous page)

Conclusion: Knowledge about HPV and cervical cancer as well as vaccine uptake was low. Results highlight the need for educational interventions about HPV and cervical cancer. These actions may contribute to improve adherence to HPV vaccination.

Keywords: Human papillomavirus (HPV), Cervical cancer, HPV vaccine, Vaccine uptake, Knowledge, Adolescent girls

\section{Background}

Cervical cancer is the fourth most prevalent type of tumor and the fourth cause of cancer death in women. In 2018, it was estimated 569,847 (3.2\%) new cervical cancer cases and 311,365 (3.3\%) deaths worldwide [1]. This cancer is more incident in developing countries, because of less access to prevention, screening, and treatment programs [1]. In Brazil, cervical cancer is the third most common cancer and the second cause of death by cancer among women. In 2018, it was estimated an incidence of 15.43 cases per 100,000 Brazilian women [2].

Persistent infection by high-risk Human Papillomavirus (HPV) is the main cause of cervical cancer [3]. More than $160 \mathrm{HPV}$ types have been characterized and about 40 can infect anogenital tract and other mucosal epithelia $[4,5]$. HPV6 and 11, classified as low-risk, account for most cases of genital warts. Conversely, high-risk HPV types, particularly HPV16 and 18 are associated with $70 \%$ of cervical cancer and precancerous cervical lesions [6].

The highest rates of HPV infection are observed in women less than 25 years of age [7]. A survey conducted in the United States with women aged 14 to 65 years showed that sexually active adolescents aged 14 to 19 years (35\%) presented the highest prevalence of high-risk HPV infection [8]. In São Paulo, Brazil, the prevalence of high-risk HPV infection in women aged 15 to 65 years was $17.8 \%$, with a higher rate among women under 25 years (27.1\%) [9]. A study conducted in Rio Grande do Sul State, Brazil, including women with a mean age of 32.7 years demonstrated that patients aged 20 years or younger were at increased risk of HPV infection [10]. In Ouro Preto, Minas Gerais, a similar study showed a high prevalence of HPV infection in women younger than 30 years old (17.2\%), who also had a risk of HPV infection approximately four times higher than women aged 50 years and older [11].

To reduce the cases of cervical cancer and HPVrelated diseases, prophylactic HPV vaccines have been developed as a primary prevention strategy. The bivalent vaccine protects against HPV16 and 18, and the quadrivalent vaccine protects against HPV types $6,11,16$ and 18 [12, 13]. Currently, the 9-valent HPV vaccine is available in the United States and includes an additional five HPV types namely HPV 31, 33, 45, 52 and 58 [13]. HPV vaccines are preferentially recommended for adolescents aged 9 to 14 years because this group had been less exposed to the virus through sexual intercourse and have shown the greatest immune response [12, 13].

In 2006, the United States, Australia, and Canada were among the first countries to implement HPV vaccination, and by the end of 2016, HPV vaccine was introduced into the national immunization programs in 74 countries [14]. Quadrivalent HPV vaccine was provided free in Brazilian routine vaccination schedule since 2014. In the first year, the target population was adolescents girls aged 11 to 13 years. Currently, HPV vaccine is available for girls aged 9 to 14 , and boys aged 11 to 14 [15].

HPV vaccines are considered safe and effective for the prevention of HPV infection [12, 13]. However, a decrease in uptake has been observed since the incorporation of HPV vaccine in Brazil. In 2014, vaccine uptake for the first dose was $85 \%$, but for the second dose, there was a reduction to $60 \%$. In 2018 , uptake to the initial dose remained high (79.2\%), but there was also a drop in adherence to the second dose $(48.7 \%)[15,16]$. Studies have shown some barriers regarding vaccination such as the belief that adolescents are too young to receive a vaccine against a sexually transmitted infection (STI), concerns about adverse effects of the vaccine, and lack of information about the HPV vaccine [17-19]. Knowledge about HPV and HPV vaccine varies in the general population and is an important factor in the acceptance of vaccination $[17,20]$. Thus, some studies have been carried out to assess the knowledge of the population in several countries about HPV, HPV vaccine, and cervical cancer [21-23]. However, to the best of our knowledge, no study to date has evaluated the knowledge among under 15 years girls in Brazil, the main target population of HPV vaccination.

The present study aimed to assess knowledge of adolescent girls and their mothers/guardians about HPV, HPV vaccine and cervical cancer, and also identify the factors associated with this knowledge, and to evaluate the immunization dropout rate. The results may contribute to health promotion actions aimed to improve adherence to vaccination and other HPV prevention methods to reduce HPV incidence and other STI.

\section{Methods}

Ethical statement

This study was approved by the Human Research Ethics Committee of Universidade Federal de Ouro Preto 
(protocol number 858,572). All procedures in this study are in accordance with the resolution number 466/12 of the Brazilian National Health Council.

\section{Study design and participants}

A cross-sectional study was conducted in Ouro Preto, state of Minas Gerais, Brazil, between 2014 and 2016.

Ouro Preto is a small town with a population of 70 , 281 inhabitants, and 36,004 (51.2\%) are women. It is located about $100 \mathrm{~km}$ from Belo Horizonte, the capital of the state of Minas Gerais [24].

The study population consisted of adolescents who were between 11 and 13 years old in March 2014. March was used with reference, as this was the month that started the free HPV vaccination program in Brazil for adolescents of this age group. In addition to adolescent girls, their mothers/guardians were included in the study.

Sample size calculation was based on a population of 1750 adolescent girls between 11 and 13 years old. A list of name, age, and address of adolescent girls and their mothers/guardians was provided by Municipal Health Service. Prevalence of knowledge and perception about HPV and cervical cancer as "Good/Very Good" was estimated to be $13 \%$. This prevalence was defined in a pilot study carried out with adolescent girls and mothers enrolled in two Basic Health Care Units of Ouro Preto.

Considering a confidence interval of $95 \%$ (95\% CI) and an error of $2 \%$, a sample size of approximately 670 adolescent girls was obtained.

\section{Data collection}

With the support of health care teams, adolescent girls and their mothers/guardians were visited at their residences in urban and rural areas or were invited to attend the nearest Basic Health Care Units. The recruitment of some adolescent girls also took place in schools. The adolescent girls and mothers/guardians were informed about the purpose of study and invited to participate in the research. The adolescent girls and mothers/guardians who agreed to take part in the study all signed the assent and informed consent, respectively. All adolescent girls also needed an authorization of their mother/guardian obtained by form of written consent. Interviews were conducted by female undergraduate and graduate students who received prior training to perform this function. Adolescent girls and mothers/guardians were individually interviewed ensuring privacy. The mean time of each interview was $15 \mathrm{~min}$.

Two specific interviews were developed, one for adolescent girls and another for mothers/guardians. The items in the interviews were elaborated based on previous surveys conducted in Brazil and other countries, considering the aim of the present study and local specificities [17, 25-28]. This instrument was piloted with adolescent girls and mothers attending two Basic Health Care Units. The wording of the interviews was modified based on the comments of the participants, aiming to improve understanding and ensure the validity of the responses. The two interviews contained similar items, being composed by multiple-choice and open questions that addressed: sociodemographic data, sexual and gynecological history, as well as knowledge about HPV, HPV vaccine, and cervical cancer.

In the knowledge assessment section, initially the participants were asked if they had heard of HPV vaccine and then of HPV infection. Adolescent girls and mothers/guardians who reported had never heard of these subjects did not answer the corresponding questions and were classified as low knowledge. Only those who answered affirmatively about awareness of HPV vaccine were asked to respond to the following open questions: How many doses of HPV vaccine should be given? What is the interval between HPV vaccine doses? Who should get HPV vaccine? Does HPV vaccine prevent other sexually transmitted infections?

Similarly, those who answered "yes" about awareness of HPV infection were invited to respond to specific questions on this topic, such as: What is the main transmission route of HPV? What should women do to prevent HPV infection? Does HPV infection have visible signs and symptoms? What are the signs and symptoms of HPV infection? Is HPV infection common? What kinds of problems does infection with HPV cause? What causes cervical cancer? Why should we prevent HPV infection?

Immunization records were used as data source to investigate the HPV vaccination uptake. These records were made available by the immunization sector of Ouro Preto's Municipal Health Service.

\section{Data analysis}

Interviews were coded and doubly typed in EpiData software, version 3.1. Subsequently, validation of doubleentry, conference, and correction of divergences of typing was performed. Data analysis was carried out using Stata/SE software, version 14.

Answers to open questions were categorized according to their similarities and were later classified as correct or incorrect. Participants were given one point for each correct answer, and zero for incorrect answers or "do not know". These points were added up and the knowledge was categorized as high or low. For categorization, the third quartile $(\mathrm{Q} 3)$ of the total score was established as a cutoff. Finally, knowledge was classified as high according to the following criterion: adolescent girl - more than four correct answers in a total of 13 questions; mothers/guardians - more than five correct answers in a 
total of 10 questions. As the interview of adolescent girls and mothers/guardians had a different number of questions, it was necessary to transform the absolute number of correct answers in percentage to compare the grade of knowledge between the groups. This percentage was calculated according to the number of correct answers of each participant based on the total questions that assessed the knowledge of each group. The comparison of knowledge between the groups was performed using the Mann-Whitney test.

Poisson regression with robust variance estimation was performed to evaluate factors associated with knowledge of adolescent girls and the mothers/guardians using incidence rate ratio (IRR) with 95\% CI. Initially, univariate analysis was carried out and variables with $p$ value $<0.25$ were selected. The univariate model was composed by all sociodemographic and behavioral variables, and vaccine uptake. The variables selected in this process were grouped in a model with successive discard (backward selection) of the non-significant variables, thereby considering the effects of these variables on knowledge. Thus, only variables with $p$ value $<0.05$ remained in the final multivariate model.

Vaccine uptake was based on the receipt of two doses of HPV vaccine and was assessed by the immunization dropout rate. Thus, it was considered dropout the adolescent girl who received only one dose of HPV vaccine and did not complete the two-dose schedule. This is an indicator used for multi-dose vaccines and was calculated using the formula: Dropout rate $=[$ (number of initial vaccine doses - number of ending vaccine doses) $\div$ (number of initial vaccine doses) $\times 100]$. The following parameters were used to analyze the immunization dropout rate: (i) low dropout rate $<5 \%$; (ii) mean dropout rate $\geq 5$ and $<10 \%$; and (iii) high dropout rate $\geq 10 \%[29,30]$.

\section{Results}

A total of 666 adolescent girls and 623 mothers/guardians participated in the study. Forty-three mothers/ guardians were responsible for more than one adolescent girl. Table 1 shows the sociodemographic and behavioral characteristics of the participants.

Mean age of adolescent girls was $12.4 \pm 1.0$ years. It was observed that $59.9 \%(n=398 / 665)$ of adolescent girls were in the 7th and 8th grades of middle school and $59.5 \%(n=396 / 666)$ resided in urban area. Most of them followed catholic religion $(n=500 / 666 ; 75.1)$. Only $1.6 \%$ $(n=11 / 666)$ of adolescent girls had sexual intercourse. Furthermore, $65.5 \%(n=436 / 666)$ of them received twodose of HPV vaccine (Table 1).

The age range of guardians was 18 to 77 years, with mean of $40.6 \pm 10.1$ years. Most were mothers $(n=489$ / $623 ; 78.5 \%)$, had elementary school or less $(n=336 / 621$; $54.1 \%)$, and followed catholic religion $(n=473 / 623$;
75.9\%). Regarding household income, 80.2\% $(n=482 /$ 601) of mothers/guardians reported to earn US $\$ 750$ or less per month (Table 1). Concerning sexual life, few mothers/guardians $(n=32 / 623 ; 5.1 \%)$ reported to have received a diagnosis of a STI, with the most common being HPV infection $(n=9 / 32 ; 28.1 \%)$. Among the 489 mothers in this study, $4.3 \%(n=21 / 489)$ never had a Pap smear. Regarding the number of exams, 30.8\% $(n=144 /$ 468) of mothers had up to five Pap smears, $72.6 \%$ ( $n=$ $340 / 468)$ said they performed it annually, and $69.2 \%$ $(n=324 / 468)$ had performed in the last 12 months or less (data not shown).

\section{Knowledge about HPV vaccine}

Mothers/guardians answered correctly the questions for the knowledge evaluation more often than adolescent girls. When asked about the concept of the vaccine, $71.5 \%(n=476 / 666)$ of adolescent girls and 79.9\% $(n=$ $498 / 623$ ) of the mothers/guardians correctly cited its prophylactic nature. Regarding the HPV vaccine, almost half of adolescent girls $(n=330 / 666 ; 49.5 \%)$ knew the number of doses adopted by the official immunization schedule. However, only $11.6 \%(n=77 / 666)$ knew about the correct interval between doses, and 39.2\% $(n=244$ / 623) of mothers/guardians correctly identified the HPV vaccination target population. In addition, only $18.3 \%$ $(n=122 / 666)$ of adolescent girls and 26\% $(n=162 / 623)$ of mothers/guardians did not believe that HPV vaccine prevents other STIs; some participants cited that HPV vaccine might prevent the Human Immunodeficiency Virus Infection (HIV) and syphilis (Table 2). Concerning the main sources of information about the HPV vaccine, $27.5 \%(n=183 / 666)$ of adolescent girls and 36.4\% $(n=$ 227/623) of mothers/guardians reported that information was obtained from television or radio. Adolescent girls also obtained information from schools $(n=149 / 666$; $22.4 \%$ ), while health care providers were poorly cited by both adolescent girls $(n=80 / 666 ; 12 \%)$ and mothers/ guardians $(n=103 / 623 ; 16.5 \%)$ (data not shown).

\section{Knowledge about HPV and cervical cancer}

Few adolescent girls ( $n=199 / 666$; 29.9\%) were able to explain what STI is. Consequently, more mothers/guardians $(n=242 / 623 ; 38.8 \%)$ than adolescent girls $(n=98 / 666$; $14.7 \%)$ correctly indicated that HPV is mainly transmitted through sexual contact. On the issue of what should be done to prevent HPV infection, $23.3 \%(n=158 / 666)$ of adolescent girls cited vaccination, condom use, and/or avoid having multiple sexual partners (Table 2). Therefore, $11.6 \%(n=77 / 666)$ of adolescent girls limited prevention to receiving the HPV vaccine, and $12 \%(n=80 / 666)$ indicated condom use as the primary method of HPV prevention (data not shown). 
Table 1 Sociodemographic and behavioral characteristics of adolescent girls and their mothers/guardians

\begin{tabular}{|c|c|c|c|c|}
\hline \multirow[t]{2}{*}{ Characteristics } & \multicolumn{2}{|l|}{ Adolescent girls } & \multicolumn{2}{|l|}{ Mothers/Guardians } \\
\hline & Categories & n (\%) & Categories & n (\%) \\
\hline \multirow[t]{3}{*}{ Age $^{*}$} & 11 years & $162(24.3)$ & $\leq 35$ years & $208(33.5)$ \\
\hline & 12 years & $199(29.9)$ & $36-49$ years & $308(49.5)$ \\
\hline & $\geq 13$ years & $305(45.8)$ & $\geq 50$ years & $106(17.0)$ \\
\hline \multirow[t]{3}{*}{ Educational level** } & $\leq 6$ th grade of elementary school & $189(28.4)$ & $\begin{array}{l}\text { Illiterate/Elementary school } \\
\text { (incomplete or complete) }\end{array}$ & $336(54.1)$ \\
\hline & 7th-8th grades of middle school & $398(59.9)$ & High school (incomplete or complete) & $235(37.8)$ \\
\hline & $\begin{array}{l}\text { 9th grade of middle school - 1st year } \\
\text { of high school }\end{array}$ & $78(11.7)$ & Higher education (incomplete or complete) & $50(8.1)$ \\
\hline \multirow[t]{2}{*}{ Residence area } & Rural & $270(40.5)$ & Rural & $244(39.2)$ \\
\hline & Urban & $396(59.5)$ & Urban & $379(60.8)$ \\
\hline \multirow[t]{3}{*}{ Household income (monthly)*** } & - & - & $\leq$ US\$750 & $482(80.2)$ \\
\hline & - & - & US\$751-1500 & $103(17.1)$ \\
\hline & - & - & >US\$1500 & $16(2.7)$ \\
\hline \multirow[t]{3}{*}{ Religion } & No & $48(7.2)$ & No & $24(3.8)$ \\
\hline & Catholic & $500(75.1)$ & Catholic & $473(75.9)$ \\
\hline & Others & $118(17.7)$ & Others & $126(20.2)$ \\
\hline \multirow[t]{5}{*}{ Marital Status } & - & - & Married & $369(59.2)$ \\
\hline & - & - & Partner & $83(13.3)$ \\
\hline & - & - & Single & $94(15.1)$ \\
\hline & - & - & Widowed & $33(5.3)$ \\
\hline & - & - & Separated/Divorced & $44(7.1)$ \\
\hline \multirow[t]{2}{*}{ Boyfriend } & No & $577(86.6)$ & - & - \\
\hline & Yes & $89(13.4)$ & - & - \\
\hline \multirow[t]{2}{*}{ Sexual intercourse****} & No & $654(98.4)$ & No & $3(0.5)$ \\
\hline & Yes & $11(1.6)$ & Yes & $595(99.5)$ \\
\hline \multirow[t]{4}{*}{ Age of 1st sexual intercourse ${ }^{* * * * *}$} & $9-12$ years & $2(18.2)$ & $\leq 15$ years & $137(23.0)$ \\
\hline & $13-14$ years & $7(63.6)$ & $16-20$ years & $303(50.9)$ \\
\hline & 15 years & $2(18.2)$ & $>20$ years & $134(22.5)$ \\
\hline & & & Did not know & $21(3.6)$ \\
\hline \multirow[t]{3}{*}{ Number of sexual partners ${ }^{* * * *}$} & 1 & $8(72.7)$ & 1 & $282(48.5)$ \\
\hline & 2 & $1(9.1)$ & $\geq 2$ & $274(47.2)$ \\
\hline & $\geq 3$ & $2(18.2)$ & Did not know & $25(4.3)$ \\
\hline \multirow[t]{3}{*}{ Vaccine uptake } & None dose & $22(3.3)$ & - & - \\
\hline & One dose & $208(31.2)$ & - & - \\
\hline & Two doses & $436(65.5)$ & - & - \\
\hline
\end{tabular}

* Some adolescent girls were interviewed with more than 13 years old because the recruitment period was from 2014 to 2016 . One guardian did not report the age

** One adolescent girl was not attending school. Two guardians did not know their level of education

*** Twenty-two guardians did not report on household income

**** One adolescent girl and twenty-five mothers/guardians did not report about sexual intercourse

***** Variables evaluated only for participants who reported having started sexual intercourse. Fourteen mothers/guardians did not report on the number of sexual partners

The two groups were also unaware of signs and symptoms of HPV infection, as only $1.0 \%(\mathrm{n}=7 / 666)$ of adolescent girls and $5.8 \%(n=36 / 623)$ of mothers/ guardians mentioned that genital warts may be a visible sign of infection. Furthermore, few adolescent girls $(n=169 / 666 ; 25.4 \%)$ and mothers/guardians $(n=$ $112 / 623 ; 18.0 \%)$ knew that HPV infection is common (Table 2). 
Table 2 Frequency of correct answers knowledge assessment about HPV, HPV vaccine, and cervical cancer of adolescent girls and mother/guardians

\begin{tabular}{|c|c|c|}
\hline Questions $^{\mathrm{a}}$ & $\begin{array}{l}\text { Adolescent girls } \\
\mathrm{n}(\%)\end{array}$ & $\begin{array}{l}\text { Mothers/Guardians } \\
\mathrm{n}(\%)\end{array}$ \\
\hline \multicolumn{3}{|l|}{ Knowledge about HPV vaccine } \\
\hline 1- What are vaccines? & $476(71.5)$ & $498(79.9)$ \\
\hline 2- How many doses of HPV vaccine should be given? & $330(49.5)$ & - \\
\hline 3- What is the interval between HPV vaccine doses? & $77(11.6)$ & - \\
\hline 4- Who should get HPV vaccine? & - & $244(39.2)$ \\
\hline 5- Does HPV vaccine prevent other sexually transmitted infections? & $122(18.3)$ & $162(26.0)$ \\
\hline \multicolumn{3}{|l|}{ Knowledge about HPV and cervical cancer } \\
\hline 6- What is a sexually transmitted infection? & $199(29.9)$ & - \\
\hline 7- What is the main transmission route of HPV? & $98(14.7)$ & $242(38.8)$ \\
\hline 8- What should women do to prevent HPV infection? & $158(23.3)$ & - \\
\hline 9- Does HPV infection have visible signs and symptoms? & $125(18.8)$ & $159(25.5)$ \\
\hline 10- What are the signs and symptoms of HPV infection? & $7(1.0)$ & $36(5.8)$ \\
\hline 11- Is HPV infection common? & $169(25.4)$ & $112(18.0)$ \\
\hline 12- What kinds of problems does infection with HPV cause? & $89(13.4)$ & $204(32.7)$ \\
\hline 13- What causes cervical cancer? & $14(2.1)$ & $56(9.0)$ \\
\hline 14- Why should we prevent HPV infection? & $55(8.3)$ & - \\
\hline 15- What is a Pap smear? & - & $498(79.9)$ \\
\hline
\end{tabular}

${ }^{2}$ Answers rated as correct: 1- Prevention of disease/To stay protected/Immunity. 2- Two-dose or three-dose. 3-0-6 months. 4- Adolescent girls 11-13 years old or 913 years old. 5- No/Only against HPV/Each disease has a specific vaccine. 6- Disease transmitted through sexual intercourse/Disease that is caught through sex and may be transmitted to someone else. 7- Sexual intercourse. 8- Get the vaccine/Avoid multiple sexual partners/Use a condom. 9- No/Asymptomatic/Silent disease. 10- Genital warts. 1 1- Yes. 12- Cancer/Cervical cancer/Uterine cervix disease/Warts genital. 13- HPV infection. 14- Prevent cancer/Prevent HPV/Prevent cervical cancer. 15- Examination to prevent cervical cancer/Collection of material, secretion or liquid

Awareness of what HPV infection can cause was another important point. However, only $13.4 \%(n=89 / 666)$ of adolescent girls and 32.7\% $(n=204 / 623)$ of mothers/ guardians showed knowledge about the issue. Consequently, few adolescent girls $(n=14 / 666 ; 2.1 \%)$ and mothers/guardians $(n=56 / 623 ; 9.0 \%)$ were able to recognize the relationship between HPV infection and occurrence of cervical cancer, and less than 9.0\% $(n=$ 55/666) of adolescent girls knew why it is important to prevent HPV infection. On the other hand, most mothers/guardians $(n=498 / 623 ; 79.9 \%)$ correctly described how the Pap smear is performed and knew its purpose (Table 2).

\section{Comparison between the knowledge of adolescent girls and mothers/guardians}

The knowledge score was determined based on the number of correct answers. Most of adolescent girls $(n=512 / 666 ; 76.9 \%)$ and mothers/guardians $(n=497 /$ $623 ; 79.8 \%$ ) presented low knowledge on the subject. Comparing the percentage of correct answers between groups showed that mothers/guardians presented the highest index, with $30 \%(\mathrm{Q} 1=20 \%$; $\mathrm{Q} 3=50 \%)$ as the median of correct answers. This percentage was significantly higher $(p<0.0001)$ than results of adolescent girls, who scored a median of correct answers of $15.4 \%(\mathrm{Q} 1=$ 7.7\%; Q3 = 30.8\%) (Fig. 1).

\section{Assessment of factors related to knowledge}

The factors that could influence knowledge about HPV and cervical cancer for adolescent girls that showed to be significant in the univariate analysis $(p<0.25)$ included the variables: age, educational level, religion, and household income (reported by mother/guardian) (Table 3). The variable educational level was not included in multivariate analysis because it is collinear with the variable age. After successive removal of variables, the following factors were associated with risk of having low knowledge in the multivariate analysis: (i) age of 12 years [IRR 1.2 (95\% CI 1. 1-1.3)] and age of 11 years [IRR 1.3 (95\% CI (1. 2-1.4)], when compared to age of 13 years or more; (ii) household income lower or equal than US\$750 per month [IRR 1.7 (95\% CI 1. 12.6)] and household income between US\$751 and US\$1500 per month [IRR 1.6 (95\% CI 1.0-2.6)] when compared to household income higher than US\$1500 per month (Table 3).

For mothers/guardians, the variables educational level, residence area, household income, to be married and religion obtained $p$ value $<0.25$ by the univariate analysis. Thus, factors associated with risk of low knowledge of 


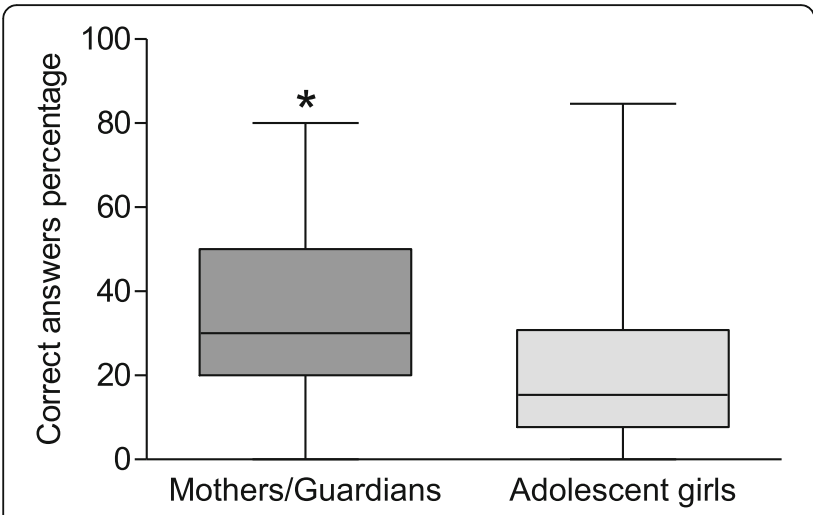

Fig. 1 Distribution of the percentage of correct answers given by mothers/guardians and adolescent girls to knowledge assessment questions about HPV, HPV vaccine, and cervical cancer. The *

represents the significant difference between the knowledge grade of mothers/guardians and adolescent girls

mothers/guardians were: (i) to be illiterate, not having or having completed elementary school [IRR 1.5 (95\% CI 1. 2-2.0)] versus having or not having complete higher education; (ii) household income lower or equal than US\$750 per month [IRR 1.2 (95\% CI 1.0-1.4)], if compared with household income between US\$751 and US\$1500 per month (Table 3).

About one third ( $n=208 / 666 ; 31.2 \%)$ of the adolescent girls received only one dose of the HPV vaccine, and $3.3 \%(n=22 / 666)$ did not receive any dose at all of the vaccine (Table 1 ). It was also evaluated the association between vaccination uptake and knowledge of both adolescent girls [IRR 1.0 (95\% CI 0. 9-1.1)] and mothers/ guardians [IRR 1.0 (95\% CI 0. 9-1.0)], and results indicated no significant association.

\section{Immunization dropout rate among adolescent girls}

The dropout rate was determined by the proportion of adolescent girls who received the first dose of the vaccine and dropped out before completing the two-dose vaccination schedule. A high rate of uptake of the initial dose of HPV vaccine (96.7\%) was observed. However, only $65.5 \%$ of adolescents completed the schedule, which is lower than $80 \%$ goal recommended by the Brazilian Ministry of Health [15]. Thus, the dropout rate in our sample was high, at $32.3 \%$.

\section{Discussion}

The present study shows that knowledge about HPV and cervical cancer is low for Ouro Preto's adolescent girls and their mothers/guardians. However, based upon the percentage of correct answers, it was observed that, as expected, mothers/guardians had more knowledge than adolescent girls. Sociodemographic factors, such as age, educational level, and household income interfered in the grade of knowledge of the participants about the subject. HPV immunization dropout rate was high $(32.3 \%)$, but there was no association with low knowledge.

Most of the participants were unaware of the causal relationship between HPV and cervical cancer or between HPV and the development of genital warts. In addition, adolescent girls and mothers/guardians did not know that HPV infection is common, and they had low knowledge about signs and symptoms, and the route of transmission of this infection. Similar results were found in a study that analyzed the knowledge of women in the city of Natal, capital of the northeastern state of Rio Grande do Norte, Brazil, in which few interviewees cited correctly the mode of transmission of HPV, the signs and symptoms of virus infection, and correlated HPV infection with the occurrence of cervical lesions [31]. In contrast, $74.1 \%$ of adolescent girls and $67.6 \%$ of their mothers in Hong Kong correlated HPV infection with cervical cancer [19].

In our sample, higher knowledge was observed concerning the broader concept of vaccine and, consequently, its prophylactic purpose. However, participants had a superficial knowledge about the specifics of the HPV vaccine, such as the recommended age group for vaccination, and number and interval between doses, which was also evidenced in other studies [17, 22]. Moreover, $11.6 \%$ of adolescent girls understood that prevention of HPV infection was restricted to vaccination. This appreciation of HPV vaccine may be a reflection of nationwide immunization campaign, and also of confidence of the Brazilian in the efficacy of immunobiologicals. It is known that frequent use of condoms is associated with decreased rates of HPV infection as well as other STIs [32]. However, few adolescent girls (12\%) in this study considered condom use as primary method of HPV prevention. Therefore, vaccine may generate a false sense of complete protection by reducing care that leads to HPV prevention.

Another important topic in HPV prevention and cervical cancer control is the Pap smear. Among mothers in this study, approximately $95 \%$ reported having had the test at least once in their lifetime. Differently, Lima et al. [31] showed $87 \%$ coverage of the Pap smear in a study involving women in the city of Natal, Rio Grande do Norte, Brazil. In the same study, $69.4 \%$ of women performed Pap smear with a frequency of at least once every three years, as recommended in Brazil, which was lower than mothers rate of the present study (72.6\%), who reported performing the test annually. In Brazil, in general, there is no organized screening program; thus, opportunistic testing predominates, in which while some women go without screening others are over-screened, as occurred with the mothers in our study. To improve the cost-benefit ratio, while increasing the coverage of 
Table 3 Univariate and multivariate analysis of factors associated with adolescent girls and their mothers/guardians' knowledge about HPV and cervical cancer

\begin{tabular}{|c|c|c|c|c|c|c|}
\hline \multirow[t]{2}{*}{ Populations/Characteristics } & \multicolumn{2}{|l|}{ Knowledge } & \multirow{2}{*}{$\begin{array}{l}\text { IRR } \\
(95 \% C l)^{a}\end{array}$} & \multirow[t]{2}{*}{$p$-value } & \multirow{2}{*}{$\begin{array}{l}\text { IRR } \\
(95 \% \mathrm{Cl})^{\mathrm{b}}\end{array}$} & \multirow[t]{2}{*}{$p$-value } \\
\hline & $\begin{array}{l}\text { Low } \\
\text { n (\%) }\end{array}$ & $\begin{array}{l}\text { High } \\
\mathrm{n}(\%)\end{array}$ & & & & \\
\hline \multicolumn{7}{|l|}{ Adolescent girls } \\
\hline \multicolumn{7}{|l|}{ Age } \\
\hline$\geq 13$ years & $206(67.5)$ & $99(32.5)$ & 1 & - & 1 & - \\
\hline 12 years & $161(80.9)$ & $38(19.1)$ & $1.2(1.1-1.3)$ & 0.001 & $1.2(1.1-1.3)$ & 0.002 \\
\hline 11 years & $145(89.5)$ & $17(10.5)$ & $1.3(1.2-1.4)$ & 0.000 & $1.3(1.2-1.4)$ & 0.000 \\
\hline \multicolumn{7}{|l|}{ Educational level* } \\
\hline $\begin{array}{l}\text { 9th grade of middle school - 1st year } \\
\text { of high school }\end{array}$ & $40(51.3)$ & $38(48.7)$ & 1 & - & - & - \\
\hline 7th-8th grades of middle school & $300(75.4)$ & $98(24.6)$ & $1.5(1.2-1.8)$ & 0.001 & - & - \\
\hline$\leq 6$ th grade of elementary school & $171(90.5)$ & $18(9.5)$ & $1.8(1.4-2.2)$ & 0.000 & - & - \\
\hline \multicolumn{7}{|l|}{ Religion } \\
\hline Catholic & $373(74.6)$ & $127(25.4)$ & 1 & - & - & - \\
\hline Others & $97(82.2)$ & $21(17.8)$ & $1.1(1.0-1.2)$ & 0.053 & - & - \\
\hline No & $42(87.5)$ & $6(12.5)$ & $1.2(1.0-1.3)$ & 0.008 & - & - \\
\hline \multicolumn{7}{|l|}{ Household income (monthly) ${ }^{* *}$} \\
\hline$>$ US\$1500 & $9(47.4)$ & $10(52.6)$ & 1 & - & 1 & - \\
\hline$\leq$ US\$750 & $401(77.9)$ & $114(22.1)$ & $1.6(1.0-2.6)$ & 0.041 & $1.7(1.1-2.6)$ & 0.024 \\
\hline US\$751-1500 & $83(76.1)$ & $26(23.9)$ & $1.6(1.0-2.6)$ & 0.055 & $1.6(1.0-2.6)$ & 0.032 \\
\hline \multicolumn{7}{|l|}{ Mothers/Guardians } \\
\hline \multicolumn{7}{|l|}{ Educational level|*** } \\
\hline Higher education (incomplete or complete) & $27(54.0)$ & $23(46.0)$ & 1 & - & 1 & - \\
\hline High school (incomplete or complete) & $166(70.6)$ & $69(29.4)$ & $1.3(1.0-1.7)$ & 0.050 & $1.2(0.9-1.6)$ & 0.190 \\
\hline $\begin{array}{l}\text { Illiterate/Elementary school (incomplete } \\
\text { or complete) }\end{array}$ & $302(89.9)$ & $34(10.1)$ & $1.7(1.3-2.2)$ & 0.000 & $1.5(1.2-2.0)$ & 0.003 \\
\hline \multicolumn{7}{|l|}{ Residence area } \\
\hline Urban & $290(76.5)$ & $89(23.5)$ & 1 & - & - & - \\
\hline Rural & $207(84.8)$ & $37(15.2)$ & $1.1(1.0-1.2)$ & 0.009 & - & - \\
\hline \multicolumn{7}{|l|}{ Household income (monthly) ${ }^{* * * *}$} \\
\hline US\$751-1500 & $66(64.1)$ & $37(35.9)$ & 1 & - & 1 & - \\
\hline$>$ US\$1500 & $9(56.3)$ & $7(43.7)$ & $0.9(0.6-1.4)$ & 0.576 & $1.0(0.6-1.6)$ & 0.936 \\
\hline$\leq$ US\$750 & $402(83.4)$ & $80(16.6)$ & $1.3(1.1-1.5)$ & 0.001 & $1.2(1.0-1.4)$ & 0.023 \\
\hline \multicolumn{7}{|l|}{ Marital Status } \\
\hline Married & $288(78.1)$ & $81(21.9)$ & 1 & - & - & - \\
\hline Partner & $71(85.5)$ & $12(14.5)$ & $1.1(1.0-1.2)$ & 0.083 & - & - \\
\hline Single & $76(80.9)$ & $18(19.1)$ & $1.0(0.9-1.2)$ & 0.538 & - & - \\
\hline Widowed & $27(81.8)$ & $6(18.2)$ & $1.0(0.9-1.2)$ & 0.586 & - & - \\
\hline Separated/Divorced & $35(79.6)$ & $9(20.4)$ & $1.0(0.9-1.2)$ & 0.815 & - & - \\
\hline \multicolumn{7}{|l|}{ Religion } \\
\hline Catholic & $383(81.0)$ & $90(19.0)$ & 1 & - & - & - \\
\hline Others & $99(78.6)$ & $27(21.4)$ & $1.0(0.9-1.1)$ & 0.560 & - & - \\
\hline No & $15(65.5)$ & $9(37.5)$ & $0.8(0.6-1.1)$ & 0.105 & - & - \\
\hline
\end{tabular}

anivariate analysis, ${ }^{\mathrm{b}}$ Multivariate analysis

* One adolescent girl was not attending school. The variable educational level was not included in the multivariate analysis because it is collinear the variable age

** The household income of adolescent girl was reported by mother/guardian

*** Two guardians did not know their level of education

**** Twenty-two guardians did not report on household income 
the target population and decreasing cervical cancer rates, it is necessary proper implementation of early detection of cervical cancer strategies as indicated by the Brazilian Guidelines for Cervical Cancer Screening [33]. Regarding knowledge about cervical cancer screening, results showed that the most of mothers/guardians (79.9\%) interviewed the current study in Ouro Preto had a higher level of knowledge than women of the city of Natal, as only $47 \%$ of Natal's women had medium or high level of knowledge about Pap smear [31]. Although mothers/guardians recognize the importance of Pap smear to prevent cervical cancer, the fact that participants do not associate HPV infection with the development of cervical lesions may be a barrier to reduce cases of this neoplasm. Thus, there is a need to reinforce the relevance of Pap smear for early detection of cervical lesions.

Several socioeconomic, demographic, and behavioral factors may interfere with the knowledge about HPV and cervical cancer [23, 31, 34]. Having higher education, and higher household income had a positive influence on the knowledge. Indeed, we observed that older adolescents attending more advanced school levels and mothers holding a university degree and higher family income had better knowledge regarding HPV infection and prevention. These results corroborate Abreu et al., who showed that participants who reported high knowledge about HPV had a higher level of schooling and average family income $(p<$ 0.001) [35]. Individuals with higher socioeconomic status possibly have more access to information, and consequently could be more aware regarding HPV infection and prevention measures [21, 23,34,35]. The main source of information cited by participants in our study was television/radio. However, such media is not considered the most appropriate or it is not enough to improve knowledge and lead to prevention behavior [35, 36]. Moreover, low level of schooling can make it difficult to understand the content transmitted by these or other sources of information $[21,35,36]$. In our sample, few participants reported that they obtained information about the HPV vaccine from health care providers. Previous studies have shown that health providers play a key role in improving the level of knowledge and acceptability of the HPV vaccine. Health care providers should promote communication about HPV infection and its prevention, and thus bring awareness on vaccine effectiveness [34, 36, 37].

Decreasing trends in HPV immunization uptake have been observed in Brazil. According to official data, from 2014 to early 2018 , only $48.7 \%$ of adolescent girls aged 9 to 14 years completed a two-dose schedule [16]. This coverage rate is below the $80 \%$ goal recommended by the Brazilian Ministry of Health for HPV vaccination [15]. In this study, only $65.5 \%$ of adolescent girls adhered to HPV vaccination. Previous research described that adequate knowledge about HPV infection and awareness of prevention against this virus result in higher vaccine acceptance rates [18, 21, 23]. However, in our study, HPV knowledge was not associated with vaccine uptake. This may have occurred because a significant portion of participants presented important knowledge deficiencies on the subject. Thus, both adolescent girls who completed the vaccination schedule, and those who did not complete had low knowledge regarding HPV infection. In 2016, a study conducted in the northern state of Roraima, Brazil, showed a relatively high rate of nonadherence to HPV vaccination (17.3\%). The authors reported that the lack of HPV knowledge negatively influenced the acceptance of HPV vaccine by parents/ guardians of girls [18]. Other studies reported that mothers/guardians play a key role in the decisionmaking regarding vaccination uptake [23, 38-40]. Thus, there is a clear need for the optimization and qualification of the information that will be transmitted to the population regarding HPV and cervical cancer. Additional improvements in public health strategies for HPV vaccine and cervical cancer should include educational interventions tailored to different audiences with the support of health care professionals and teachers. These are considered to be potentially influential groups to promote the increase of HPV vaccine uptake [18, 19, 38, 41].

This study was conducted in a small town, so caution should be exercised in generalizing the findings to other locations. However, the number of adolescent girls and mothers/guardians interviewed was high and recruitment occurred in both urban and rural areas. In addition, it is a region with a large movement of people and the results of this study are corroborated by similar research conducted in Brazil and in other countries. Thus, the data obtained herein may guide public health actions aimed to prevent HPV infection in places with a similar population profile.

Considering that a wide interval was used to define "high knowledge", both adolescent girls and their mothers/guardians have reached a very low knowledge score. Thus, this study points to the need of implementing educational initiatives on HPV and cervical cancer. For guarantee the effectiveness of educational interventions, it is essential to look at socio-cultural diversities, the ability of understanding, and access to information of each population group [21, 34]. Furthermore, the combination of different means of communication especially schools, health care providers, and social networks, has been shown to be effective in increasing the understanding HPV infection and vaccine and induce changes of individual behaviors [36, 42].

\section{Conclusion}

Adolescent girls and mothers/guardians presented low knowledge about HPV and cervical cancer. However, 
despite the low knowledge, mothers/guardians demonstrated better understanding of the subject than the adolescent girls. High knowledge was associated with higher educational level and higher household income. In addition to low knowledge, we observed a high immunization dropout rate of HPV vaccination among adolescent girls. These findings reinforce the need for more effective educational actions regarding HPV and cervical cancer, especially in low-income population to promote awareness and prevention of this infection.

\section{Abbreviations}

Cl: Confidence interval; HIV: Human Immunodeficiency Virus; HPV: Human Papillomavirus; IRR: Incidence rate ratio; Q: Quartile; STI: Sexually transmitted infection

\section{Acknowledgements}

The authors would like to express sincere thanks to the adolescent girls, their mothers/guardians participating in the study, and also the Municipality Health Service of Ouro Preto. This study was financed in part by the Coordenação de Aperfeiçoamento de Pessoal de Nível Superior - Brasil (CAPES) - Finance Code 001.

\section{Authors' contributions}

ACSS was responsible for the collection, analysis and interpretation of the data, and drafting the paper. NNTS participated in data collection. CMC participated in the conception and design of the study. WCV guided the statistical analysis and revisions of the manuscript. AAL was responsible for the conception and design of the study, interpretation of the data and revisions of the manuscript. All authors read and approved the final manuscript.

\section{Funding}

No funding was received for the design of the study and collection, analysis, and interpretation of data and in writing the manuscript. The Coordenação de Aperfeiçoamento de Pessoal de Nível Superior - Brasil (CAPES) awarded a scholarship to author Ana Carolina da Silva Santos.

\section{Availability of data and materials}

The datasets used and/or analysed during the current study are available from the corresponding author on reasonable request.

\section{Ethics approval and consent to participate}

This study was approved by Human Research Ethics Committee of Universidade Federal de Ouro Preto (protocol number 858,572). All participants had to sign the informed consent form to be included in the study. Written consent was also obtained from the mother/guardian of all participating adolescents before any procedure was carried out.

\section{Consent for publication}

Not applicable.

\section{Competing interests}

The authors declare that they have no competing interests.

\section{Author details}

${ }^{1}$ Programa de Pós-graduação em Ciências Farmacêuticas (CiPharma), Escola de Farmácia, Universidade Federal de Ouro Preto, Campus Universitário, Morro do Cruzeiro, Ouro Preto, Minas Gerais 35.400-000, Brazil. ²Programa de Pós-graduação em Ciências Biológicas, Núcleo de Pesquisa em Ciências Biológicas (NUPEB), Universidade Federal de Ouro Preto, Ouro Preto, Brazil.

Received: 10 April 2019 Accepted: 25 February 2020

Published online: 06 March 2020

\section{References}

1. Bray F, Ferlay J, Soerjomataram I, Siegel RL, Torre LA, Jemal A. Global cancer statistics 2018: GLOBOCAN estimates of incidence and mortality worldwide for 36 cancers in 185 countries. CA Cancer J Clin. 2018;68(6):394-424. https://doi.org/10.3322/caac.21492.

2. Instituto Nacional de Câncer José Alencar Gomes da Silva (INCA). Estimativa 2018: incidência de câncer no Brasil. In: Coordenação de Prevenção e Vigilância. Rio de Janeiro: INCA, 2017. https://www.inca.gov.br/publicacoes/ livros/estimativa-2018-incidencia-de-cancer-no-brasil. Accessed 24 April 2018.

3. zur Hausen H. Papillomaviruses and cancer: from basic studies to clinical application. Nat Rev Cancer 2002;2(5):342-350. doi:https://doi.org/10.1038/ nrc798.

4. Bodily J, Laimins LA. Persistence of human papillomavirus infections: keys to malignant progression. Trends Microbiol. 2011;19(1):33-9. https://doi.org/10. 1016/j.tim.2010.10.002.

5. Burk RD, Harari A, Chen Z. Human papillomavirus genome variants. Virology. 2013;445(1-2):232-43. https://doi.org/10.1016/j.virol.2013.07.018.

6. Garland SM, Smith JS. Human papillomavirus vaccines: current status and future prospects. Drugs. 2010;70(9):1079-98. https://doi.org/10.2165/ 10898580-000000000-00000.

7. Schiffman M, Wentzensen N. Human papillomavirus infection and the multistage carcinogenesis of cervical cancer. Cancer Epidemiol Biomark Prev. 2013;22(4):553-60. https://doi.org/10.1158/1055-9965.

8. Datta SD, Koutsky LA, Ratelle S, Unger ER, Shlay J, McClain T, et al. Human papillomavirus infection and cervical cytology in women screened for cervical Cancer in the United States, 2003-2005. Ann Intern Med. 2008; 148(7):493-500. https://doi.org/10.7326/0003-4819-148-7-200804010-00004.

9. Rama CH, Roteli-Martins CM, Derchain SFM, Longatto-Filho A, Gontijo RC, Sarian LOZ, et al. Prevalência do HPV em mulheres rastreadas para o câncer cervical. Rev Saude Publica. 2008;42:123-30. https://doi.org/10.1590/S003489102008000100016

10. Oliveira GR, Vieira VC, Barral MFM, Döwich V, Soares MA, Gonçalves CV, et al. Fatores de risco e prevalência da infecção pelo HPV em pacientes de Unidades Básicas de Saúde e de um Hospital Universitário do Sul do Brasil. Rev Bras Ginecol Obstet. 2013;35(5):226-32. https://doi.org/10.1590/S010072032013000500007

11. Miranda PM, Pitol BC, Moran MS, Silva NN, Felix PM, Lima-Filho JL, et al. Human papillomavirus infection in Brazilian women with normal cervical cytology. Genet Mol Res. 2012;11(2):1752-61. https://doi.org/10.4238/2012.

12. Dochez C, Bogers JJ, Verhelst R, Rees H. HPV vaccines to prevent cervical cancer and genital warts: an update. Vaccine. 2014;32(14):1595-601. https:// doi.org/10.1016/j.vaccine.2013.10.081.

13. World Health Organization (WHO). Guide to Introducing HPV Vaccine into National Immunization Programmes. In: Department of Immunization, Vaccines and Biologicals. 2016. https://www.who.int/immunization/ documents/ISBN_9789241549769/en/. Accessed 24 April 2018.

14. Bruni L, Albero G, Serrano B, Mena M, Gómez D, Muñoz J, Bosch FX, de Sanjosé S. Human Papillomavirus and Related Diseases in the World. Summary Report 22 January 2019. In: ICO/IARC Information Centre on HPV and Cancer (HPV Information Centre). https://www.hpvcentre.net/statistics/ reports/XWX.pdf.

15. Brasil. Ministério da Saúde. Informe técnico da ampliação da oferta das vacinas papilomavírus humano 6, 11, 16 e 18 (recombinante) - vacina HPV quadrivalente e meningocócica C (conjugada). In: Secretaria de Vigilância em Saúde. Departamento de Vigilância de Doenças Transmissíveis. Coordenação Geral do Programa Nacional de Imunização. Brasília: Ministério da Saúde, 2018. http://portalarquivos2.saude.gov.br/images/pdf/2018/ marco/14/Informe-T\%2D\%2Dcnico-HPV-MENINGITE.pdf. Accessed 25 Sep 2018.

16. Brasil. Ministério da Saúde. Últimas notícias. Ministério da Saúde quer vacinar 10 milhões de jovens e adolescentes contra meningite e HPV. http://portalms.saude.gov.br/noticias/agencia-saude/42748-ministerio-dasaude-quer-vacinar-10-milhoes-de-jovens-e-adolescentes-contra-meningitee-hpv. Accessed 7 Fev 2019.

17. Marlow LA, Zimet GD, McCaffery KJ, Ostiani R, Waller J. Knowledge of human papillomavirus (HPV) and HPV vaccination: an international comparison. Vaccine. 2013;31(5):763-9. https://doi.org/10.1016/j.vaccine. 2012.11.083.

18. Farias CC, Jesus DV, Moraes HS, Buttenbender IF, Martins IS, Souto MG, et al. Factors related to non-compliance to HPV vaccination in Roraima-Brazil: a region with a high incidence of cervical cancer. BMC Health Serv Res. 2016; 16(1):417. https://doi.org/10.1186/s12913-016-1677-y.

19. Loke AY, Chan ACO, Wong YT. Facilitators and barriers to the acceptance of human papillomavirus (HPV) vaccination among adolescent girls: a comparison between mothers and their adolescent daughters in Hong 
Kong. BMC Research Notes. 2017;10(1):390. https://doi.org/10.1186/s13104017-2734-2.

20. Klug SJ, Hukelmann M, Blettner M. Knowledge about infection with human papillomavirus: a systematic review. Prev Med. 2008;46(2):87-98. https://doi. org/10.1016/j.ypmed.2007.09.003.

21. Osis MJ, Duarte GA, Sousa MH. Conhecimento e atitude de usuários do SUS sobre o HPV e as vacinas disponíveis no Brasil. Rev Saúde Pública. 2014; 48(1):123-33. https://doi.org/10.1590/S0034-8910.2014048005026.

22. Venezuela RF, Monetti MS, Kiguen AX, Frutos MC, Mosmann JP, Cuffini CG. Knowledge of the general Community in Cordoba, Argentina, on human papilloma virus infection and its prevention. Asian Pac J Cancer Prev 2016; 17(5):2689-2694. PMID: 27268652.

23. Yu Y, Xu M, Sun J, Li R, Li M, Wang J, et al. Human papillomavirus infection and vaccination: awareness and knowledge of HPV and acceptability of HPV vaccine among mothers of teenage daughters in Weihai, Shandong, China. PLoS One. 2016;11(1):e0146741. https://doi.org/10.1371/journal.pone. 0146741.

24. Brasil. Instituto Brasileiro de Geografia e Estatística. Censo demográfico 2010. https://cidades.ibge.gov.br/brasil/mg/ouro-preto/pesquisa/23/25 888?detalhes=true. Accessed 7 June 2018.

25. Rama $\mathrm{CH}$, Villa LL, Pagliusi $\mathrm{S}$, Andreoli MA, Costa MC, Aoki AL, et al. Awareness and knowledge of HPV, cervical cancer, and vaccines in young women after first delivery in São Paulo. Brazil-a cross-sectional study BMC Womens Health. 2010;10:35. https://doi.org/10.1186/1472-6874-10-35.

26. DiAngi YT, Panozzo CA, Ramogola-Masire D, Steenhoff AP, Brewer NT. A cross-sectional study of HPV vaccine acceptability in Gaborone. Botswana PLoS One. 2011;6(10):e25481. https://doi.org/10.1371/journal.pone.0025481.

27. Morales-Campos DY, Markham CM, Peskin MF, Fernandez ME. Hispanic mothers' and high school girls' perceptions of cervical cancer, human papilloma virus, and the human papilloma virus vaccine. J Adolesc Health. 2013;52(5 Suppl):S69-75. https://doi.org/10.1016/j.jadohealth.

28. Waller J, Ostini R, Marlow LA, McCaffery K, Zimet G. Validation of a measure of knowledge about human papillomavirus (HPV) using item response theory and classical test theory. Prev Med. 2013;56(1):35-40. https://doi.org/ 10.1016/j.ypmed.2012.10.028.

29. Brasil. Ministério da Saúde. Coberturas vacinais no Brasil - Período: 20102014. Brasília: Ministério da Saúde. In: Secretaria de Vigilância em Saúde. Departamento de Vigilância de Doenças Transmissíveis. Coordenação Geral do Programa Nacional de Imunização. 2015. http://portalarquivos2.saude. gov.br/images/pdf/2017/agosto/17/AACOBERTURAS-VACINAIS-NO-BRASIL\%2 D\%2D-2010-2014.pdf.

30. Baguune B, Ndago JA, Adokiya MN. Immunization dropout rate and data quality among children 12-23 months of age in Ghana. Arch Public Health. 2017;75:18. https://doi.org/10.1186/s13690-017-0186-8.

31. Lima EG, de Lima DB, Miranda CA, de Sena Pereira VS, de Azevedo JC, de Araujo JM, et al. Knowledge about HPV and screening of cervical Cancer among women from the metropolitan region of Natal. Brazil ISRN Obstet Gynecol. 2013;2013:930479. https://doi.org/10.1155/2013/930479.

32. Lam JU, Rebolj M, Dugué PA, Bonde J, von Euler-Chelpin M, Lynge E. Condom use in prevention of human papillomavirus infections and cervical neoplasia: systematic review of longitudinal studies. J Med Screen. 2014; 21(1):38-50. https://doi.org/10.1177/0969141314522454.

33. Instituto Nacional de Câncer José Alencar Gomes da Silva (INCA). Diretrizes brasileiras para o rastreamento do câncer do colo do útero. In: Coordenação de Prevenção e Vigilância. Divisão de Detecção Precoce e Apoio à Organização de Rede. Rio de Janeiro, 2016. https://www.inca.gov. br/publicacoes/livros/diretrizes-brasileiras-para-o-rastreamento-do-cancer-docolo-do-utero. Accessed 7 Aug 2019.

34. Bermedo-Carrasco S, Feng CX, Peña-Sánchez JN, Lepnurm R. Predictors of having heard about human papillomavirus vaccination: critical aspects for cervical cancer prevention among Colombian women. Gac Sanit. 2015;29(2): 112-7. https://doi.org/10.1016/j.gaceta.2014.09.005.

35. Abreu MNS, Soares AD, Ramos DAO. Soares, F. V., Nunes-Filho G, Valadão AF, Motta PG. Conhecimento e percepção sobre o HPV na população com mais de 18 anos da cidade de Ipatinga, MG, Brasil. Ciência \& Saúde Coletiva. 2018;23(3):849-60. https://doi.org/10.1590/1413-81232018233.00102016.

36. Almeida CM, Tiro JÁ, Rodriguez MA, Diamant AL. Evaluating associations between sources of information, knowledge of the human papillomavirus, and human papillomavirus vaccine uptake for adult women in California. Vaccine. 2012;30(19):3003-8. https://doi.org/10.1016/j.vaccine.2012.01.079.
37. Lee Mortensen G, Adam M, Idtaleb L. Parental attitudes towards male human papillomavirus vaccination: a pan-European cross-sectional survey. BMC Public Health. 2015;15:624. https://doi.org/10.1186/s12889-015-1863-6.

38. Walhart T. Parents, adolescents, children, and the human papillomavirus vaccine: a review. Int Nurs Rev. 2012;59(3):305-11. https://doi.org/10.1111/j. 1466-7657.2012.00991.x.

39. VanWormer JJ, Bendixsen CG, Vickers ER, Stokley S, McNeil MM, Gee J, et al. Association between parent attitudes and receipt of human papillomavirus vaccine in adolescents. BMC Public Health. 2017;17(1):766. https://doi.org/10. 1186/s12889-017-4787-5.

40. Mendes Lobao W, Duarte FG, Burns JD, de Souza Teles Santos CA, Chagas de Almeida MC, Reingold A, et al. Low coverage of HPV vaccination in the national immunization programme in Brazil: Parental vaccine refusal or barriers in health-service based vaccine delivery? PLoS One. 2018;13(11): e0206726. doi: https://doi.org/10.1371/journal.pone.0206726.

41. Reiter PL, Stubbs B, Panozzo CA, Whitesell D, Brewer NT. HPV and HPV vaccine education intervention: effects on parents, healthcare staff, and school staff. Cancer Epidemiol Biomark Prev. 2011;20(11):2354-61. https:// doi.org/10.1158/1055-9965.EPI-11-0562.

42. Rosen BL, Shew ML, Zimet GD, Ding L, Mullins TLK, Kahn JA. Human Papillomavirus Vaccine Sources of Information and Adolescents' Knowledge and Perceptions. Glob Pediatr Health. 2017; 4:2333794X17743405. doi: https://doi.org/10.1177/2333794X17743405.

\section{Publisher's Note}

Springer Nature remains neutral with regard to jurisdictional claims in published maps and institutional affiliations.

\section{Ready to submit your research? Choose BMC and benefit from:}

- fast, convenient online submission

- thorough peer review by experienced researchers in your field

- rapid publication on acceptance

- support for research data, including large and complex data types

- gold Open Access which fosters wider collaboration and increased citations

- maximum visibility for your research: over $100 \mathrm{M}$ website views per year

At BMC, research is always in progress.

Learn more biomedcentral.com/submissions 